\title{
Analytical Review and Mid-Term Forecast of the Development of the Russian Meat Market in the Context of a Pandemic of a New Coronavirus Infection
}

\author{
Elena Sazonova ${ }^{1}$, Veronica Borisova $^{1}$, Olga Kramlikh $^{2, *}$, Isabella Stefanova ${ }^{3}$, and Elena \\ Marchenkova $^{4}$ \\ ${ }^{1}$ Smolensk State Agricultural Academy, 214000 Smolensk, Russia \\ ${ }^{2}$ Financial University affiliated to the Government of the Russian Federation, Smolensk Branch, \\ 214018 Smolensk, Russia \\ ${ }^{3}$ All-Russian Scientific Research Institute of the Poultry Processing Industry, 141552 P/o Rzhavki, \\ Russia \\ ${ }^{4}$ Military Academy of Military Air Defense of the Armed Forces of the Russian Federation named \\ after Marshal of the Soviet Union A.M. Vasilevsky, 214027 Smolensk, Russia
}

\begin{abstract}
Currently, the Russian Federation has a difficult economic situation on the meat market. The problems affecting the effective development of this market were especially aggravated in the context of the new coronavirus infection pandemic, and directly affected the food security of the Russian Federation. The authors of the article reviewed the meat products market at the turn of 2019 - 2020, and also presented two options for its development for the medium term - basic and crisis ones. In addition, barriers to the export of meat products to the world market have been identified and directions for their early overcoming have been proposed. The results obtained in the course of this study not only provide an answer to the question about the role of external interventions in the economy of the state, but may become the basis for thinking about the importance of careful planning of long-term studies to assess difficult-topredict risks, such as a new coronavirus infection, in terms of concerning the food security of the state.
\end{abstract}

\section{Introduction}

Currently, a difficult situation has developed on the Russian meat market. Leading experts forecast an increase in meat production in Russia in the medium term, despite the tendencies for the devaluation of the Russian ruble and a decrease in the level of income among the population. It is noted that production growth will be achieved by increasing export volumes, as well as stabilizing and promoting domestic consumption of meat products. However, the profitability of this industry will gradually decline due to higher feed prices. It is necessary to consider the main options for the development of the meat

\footnotetext{
* Corresponding author: kramlikh.olga@yandex.ru
} 
market in Russia in order to overcome the barriers to its development in the medium term, taking into account the influence of negative production factors associated with the emergence of a new coronavirus infection.

For the basic variant of the development of the Russian market of meat products, the following directions will be characteristic. In connection with the commissioning of new production facilities, which had been launched earlier in the framework of various agricultural projects, a large increase in the volume of pork production in Russia will be achieved. Prices for chicken meat are also expected to rise. In addition, a slowdown in the growth of profits of domestic meat agricultural producers is possible (by an average of $10 \%$ ). At the same time, the margins of the ten largest companies producing meat products in Russia will also decrease - approximately within 5-7\%.

Previously, it was assumed that quarantine measures to prevent the development of a new coronavirus infection will last only until the end of the first half of 2020. At the moment, quarantine measures have been extended until the end of the first quarter of 2021. The second and third waves of new coronavirus infection are expected in Russia. These events will entail a decrease in the gross domestic product of Russia at the end of 2020 to 5 $6 \%$, and a drop in the total income of the population is predicted on average by $10 \%$ [1]. With such trends in the development of the events, the demand in the meat products market may recover closer to July-August 2021. In the event of the onset of the acute phase of a pandemic of a new coronavirus infection, agricultural producers will begin to fight for the main sales channel for meat products, that is, retail trade. Note that domestic consumption of all types of meat products in Russia will remain at the level corresponding to 2019, approximately 77 kilograms per person (Table 1). Naturally, consumer preferences will be redistributed towards cheaper types of meat products.

According to Table 1, we have that Russian agricultural producers of pork meat will increase the volume of production, since the existing investment projects for pig breeding in this period of time will reach the maximum amount of financing in Russia [4]. The growth of pork production volumes will be rational in conjunction with its export potential. During a pandemic of a new coronavirus infection in the world, the population is experiencing a deficiency of animal protein. Additionally, we note that at the end of 2020, an increase in profits attributable to the ten largest agricultural producers in Russia is possible. It can be about $10 \%$. Compared to the same period last year, the decline in profit will be at least $9 \%$. Product profitability in gross volume will decrease by at least $5 \%$. At the same time, the cost of meat products will grow at a faster pace than the level of profit, which ultimately may lead to the bankruptcy of many agricultural producers in Russia.

The crisis scenario of the development of the Russian meat market will be characterized by a general decline in prices for all types of meat, a not very significant increase in the production of chicken and beef meat. It should also be noted that revenue growth is not expected even among large agricultural producers. Moreover, their marginality is likely to be negative.

Table 1. Development options for the Russian meat market in 2020-2021 [4]

\begin{tabular}{|c|c|c|c|c|c|c|c|}
\hline \multicolumn{2}{|r|}{ Indicator } & \multirow{2}{*}{$\begin{array}{l}2019 \\
\text { (fact) }\end{array}$} & \multirow{2}{*}{$\begin{array}{c}\mathbf{Q 4} \\
\mathbf{2 0 2 0} \\
\text { (fact) }\end{array}$} & \multicolumn{2}{|c|}{ Basic option } & \multicolumn{2}{|c|}{ Crisis option } \\
\hline & & & & 2020 & 2021 & 2020 & 2021 \\
\hline \multicolumn{2}{|c|}{$\begin{array}{c}\text { Total meat consumption, } \\
\mathrm{kg} / \text { person per year }\end{array}$} & 77 & - & \multicolumn{2}{|c|}{77} & \multicolumn{2}{|c|}{75} \\
\hline \multirow{3}{*}{ 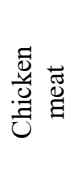 } & $\begin{array}{c}\text { Share of consumption, } \\
\%\end{array}$ & 47 & - & \multicolumn{2}{|c|}{62} & \multicolumn{2}{|c|}{73} \\
\hline & Price per $1 \mathrm{~kg}$, RUB. & 103.5 & 106.7 & \multicolumn{2}{|c|}{$+5 \%$} & \multicolumn{2}{|c|}{$-2 \%$} \\
\hline & $\begin{array}{c}\text { Volume of production, } \\
\text { thousand tons }\end{array}$ & 6300 & 1630 & \multicolumn{2}{|c|}{$+2 \%$} & \multicolumn{2}{|c|}{$+1 \%$} \\
\hline
\end{tabular}


Table 1. Continued

\begin{tabular}{|c|c|c|c|c|c|}
\hline \multirow{3}{*}{ 产 } & $\begin{array}{c}\text { Share of consumption, } \\
\%\end{array}$ & 33 & - & 23 & 18 \\
\hline & Price per 1 kg, RUB. & 133.7 & 135 & $+3 \%$ & $-3 \%$ \\
\hline & $\begin{array}{l}\text { Volume of production, } \\
\text { thousand tons }\end{array}$ & 4400 & 1153 & $+9 \%$ & $+5 \%$ \\
\hline \multirow{3}{*}{$\underset{\mathscr{D}}{\mathscr{D}}$} & $\begin{array}{c}\text { Share of consumption, } \\
\%\end{array}$ & 20 & - & $15 \%$ & $10 \%$ \\
\hline & Price per 1 kg, RUB. & 237 & 240 & $+2 \%$ & $-5 \%$ \\
\hline & $\begin{array}{l}\text { Volume of production, } \\
\text { thousand tons }\end{array}$ & 1100 & 250 & $+4 \%$ & $+1 \%$ \\
\hline \multicolumn{2}{|c|}{$\begin{array}{l}\text { Gross profitability of the } 10 \\
\text { largest agricultural producers }\end{array}$} & $23 \%$ & - & $18 \%$ & $-4 \%$ \\
\hline \multicolumn{2}{|c|}{$\begin{array}{c}\text { Revenue growth of the } 10 \\
\text { largest agricultural producers }\end{array}$} & $20 \%$ & - & $10 \%$ & $0 \%$ \\
\hline \multicolumn{2}{|c|}{$\begin{array}{l}\text { Volume of export of products, } \\
\text { thousand tons }\end{array}$} & 327 & - & 500 & 400 \\
\hline
\end{tabular}

Quarantine measures to prevent the spread of the new coronavirus infection in Russian regions may take longer than currently predicted. Expectations were confirmed, the second wave of a new coronavirus infection in Russia began in the 4th quarter of 2020 and may last until mid-2021 [2].

With such a development of events, the volume of the Russian gross domestic product will decline by $6-8 \%$. The gross income of the population will also begin to recover no earlier than the first half of 2021. Experts note that in 2020 the overall decline in real incomes of the population in Russia will be at least $15 \%$. With a slight drop in domestic consumption of meat products in 2020, the increase in export potential will continue.

Regardless of one or another variant of the development of the Russian market of meat products, it is necessary to envisage that there will be a gradual decrease in the number of small and medium-sized companies due to their bankruptcy or absorption by stronger companies.

\section{Materials and Methods}

The methodological background of the statistical study of the Russian meat market is based on the work of many scientists. To them in the first place include: S.I.V. Antokhonova, A. Ayvazyan, M.Yu. Arkhipova, I.K. Belyaevsky, O.E. Bashina, G.L. Gromyko, T.A. Dubrova, I.I. Eliseeva, M.R. Efimova, M.V. et al.

Despite the high level of elaboration of the problem, in the modern scientific world not enough attention is paid to the issues of a comprehensive statistical analysis of the state and development trends of the Russian meat market [3]. In particular, this concerns taking into account possible transformations of the foreign economic market situation, as well as assessing the impact on the development of the market of the new coronavirus infection.

When conducting an analytical review of the Russian market of meat products, the methods of correlation and regression analysis, analysis of structural breaks, as well as tabular and graphical methods of visual presentation of data have been used as statistical tools. Also, data analysis tools from the MS Excel 2007 package have been used.

\section{Results and Discussion}

The pandemic of the new coronavirus infection has significantly affected the economic development of Russia in general and the meat market in particular. The unemployment 
rate has increased, the real income of the population has significantly decreased by the end of 2020. Similar trends may continue in the near future [5].

According to 2018 data available in the Federal State Statistics Service of Russia, the share of employed citizens in the total number of the working population in the sectors most affected by the pandemic was about $38 \%$ [6].

Note that the most affected industries include wholesale and retail trade, catering, agriculture, construction, hotel business, and logistics.

Nevertheless, in spite of the current situation in the meat market, agricultural producers intend to increase their meat production in 2020-2021. At the same time, the share of their costs in the amount of consumer spending will grow to at least $30-35 \%$. When compared with 2019 , this figure was $26 \%$.

The above review of the meat market in Russia reflects the lack of interconnection between the level of consumption of meat and meat products and the changes that are currently taking place in Russia's gross domestic product and the level of real incomes of the population. Over the past five years, there has been a steady downward trend in the level of real incomes of the population in Russia. Despite this, the volume of consumption of meat products grew throughout 2013, as well as in the period from 2016 to 2019 inclusive (Figure 1). A decrease in consumption was recorded only in 2014 and 2015.

Experts from the Agency for National Credit Ratings expect an increase in the cost of purchasing food products [1]. At the same time, non-food products will lose ground and become less significant in the consumer basket.

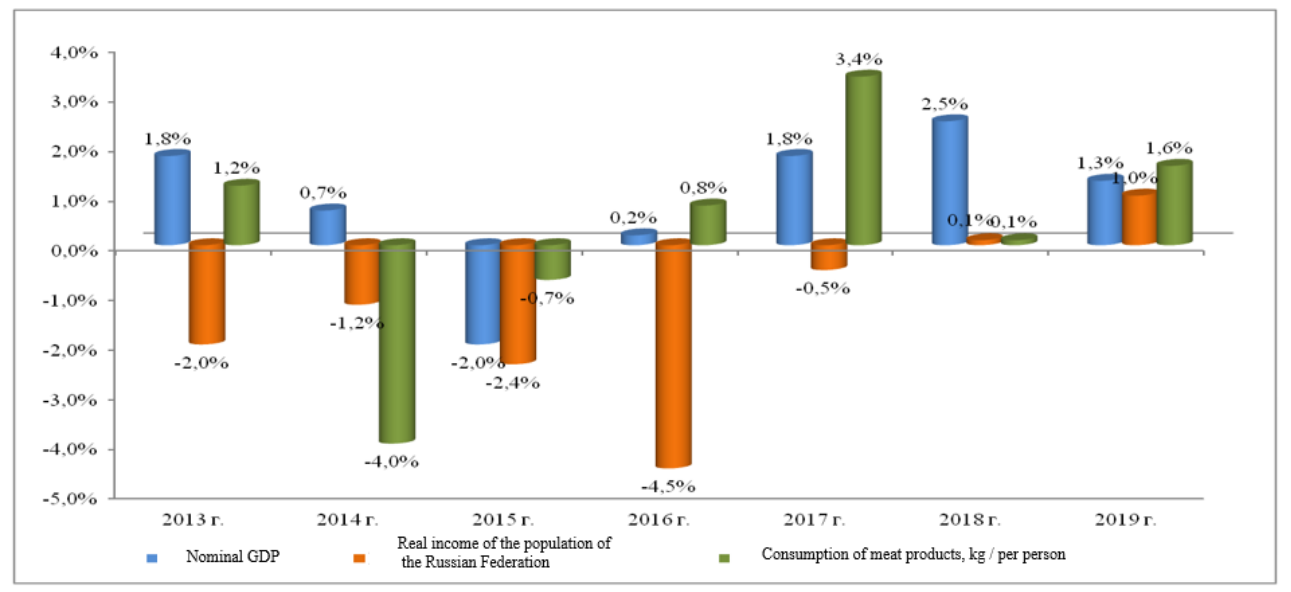

Fig. 1. Dynamics of the level of GDP, real incomes of the population and consumption of meat products in Russia in 2013-2019, in\% [6].

Even with a slight change in the proportions of consumer preferences in this market, the expenses of the population in Russia for the purchase of this type of product may grow by the end of this year by $30-35 \%$ (Figure 2). 


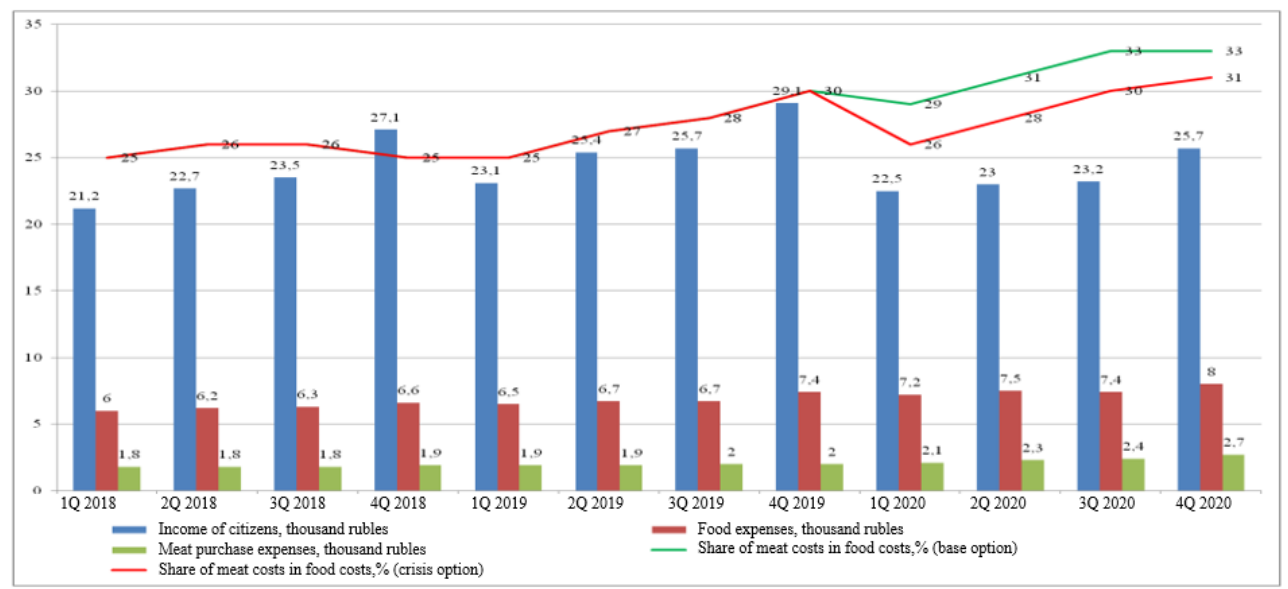

Fig. 2. Variants of changes in the volume of meat consumption in the basic and crisis scenarios of the development of the Russian economy in 2018-2020 [6].

At the same time, it is necessary to take into account the downward trend in real incomes of the population, which may entail a redistribution of consumer preferences from expensive types of products to cheaper and more affordable ones. Therefore, the cost of production and sale of meat products can grow proportionally up to 30\% (Figure 2). Most likely, consumers will give more preference to frozen products.

As for the export of meat products, it can grow due to the opening of a sales market to Vietnam (as well as to the PRC) up to 500,000 tons with the basic development option by the end of 2020. If favorable conditions are established, agricultural producers of meat in Russia can increase the volume of its supplies to the foreign market by at least $50 \%$. In the event of unfavorable conditions for the export of meat to the external market, that is, in a crisis scenario, this figure by the end of 2020 will be about 400,000 tons [7].

Note that meat imports to Russia will also decrease by about $3.5-4.5 \%$, which in monetary terms will amount to about 2 billion US dollars. At the same time, there is a tendency for a steady decrease in the cost of imports of meat and meat products in 2015 to 2020 inclusive by $67 \%$, and from 2010 to 2020 by $73 \%$, respectively. The main reasons for the reduction in the volume of imports of meat and meat products to Russia are the devaluation of the Russian ruble and an increase in the volume of its own production (the state policy of import substitution).

\section{Conclusion}

1. The novel coronavirus pandemic has had a major impact on employment levels; real incomes of the population in 2020 may decline more significantly than in previous crisis periods.

2. The volume of meat production in Russia in 2020 will grow against the background of relative stability in the domestic consumption market, despite the constant devaluation of the ruble and a decrease in real incomes of the population.

3. Exports of meat products can grow up to 500 thousand tons in 2020 under the basic scenario of economic development in Russia.

4. Self-sufficiency in meat products in Russia is close to $100 \%$, so a shortage is unlikely. Imports of meat products are also declining.

5. The largest agricultural producers of meat products are increasing their production volumes and market share even if the price level falls. 
6. The profitability of meat producers could be under significant pressure.

\section{References}

1. Agro-industrial complex, Analytical review, https://www.ratings.ru.

2. V. L. Borisova, O.Yu. Kramlich, E.A. Sazonova, Fundamental and applied research of the cooperative sector of the economy, 2, 145 (2020)

3. V.L. Borisova, Creative heritage of A. S. Posnikov and modernity, 10, 147 (2016)

4. O.Yu. Kramlich, Financial and economic aspects of international integration processes. International scientific periodical based on the results of the International scientific and practical conference, International Research Agency, 26 (2016)

5. E.A. Sazonova, I.V. Sidorenkova, Main directions and forms of development of consumer cooperation in Europe and Asia: experience, problems, prospects, Proceedings of the international scientific and practical conference in the framework of the annual Chayanov readings, 275 (2016)

6. Federal state statistics service, https://rosstat.gov.ru/

7. A.S. Shpakov, G.N. Bychkov, Bulletin of the Russian agricultural science, 6, 4 (2016) 